\title{
PENGEMBANGAN APLIKASI PEMBENTUKAN KELOMPOK COOPERATIVE LEARNING MENGGUNAKAN VISUAL BASIC
}

\author{
Agus Prasetyo Kurniawan \\ Prodi Pendidikan Matematika, Universitas Islam Negeri Sunan Ampel Surabaya
}

\begin{abstract}
This study aim to develop an application using visual basic programming to facilitate the formation of cooperative groups and to investigate the validity, effectiveness, and practicality of the development of this application. This research method including R\&D performed with 6 stage, consists of: the potential and problems, data collection, product design, design validation, improved of design, and test products. The results showed that the yield of the IT media expert validation amounted to $82.5 \%$ and validation of learning experts is $92.86 \%$. In addition, the results of the questionnaire responses test of subjects each amounted $83.33 \%$ for the first test subjects and $91.67 \%$ for the second test subjects. Seeing these findings, it can be concluded that the application of cooperative learning group formation using visual basic can be said to be very feasible to be used as a tool for the establishment of cooperative learning groups.
\end{abstract}

Keywords: Cooperative learning; Visual basic

\section{PENDAHULUAN}

Ketika peserta didik ditanya, "Tahukah kalian bagaimana menghitung volume balok?". Dengan cepat mereka menjawab, "Panjang kali lebar kali tinggi $(p \times 1 \times t)$ ". Ilustrasi ini menandakan ada sesuatu yang menggelitik di benak kita, "Apakah mereka tahu maksud dari jawabannya?”, “Apakah mereka mengerti bagaimana proses mendapatkan rumus tersebut?", Ataukah mereka hanya menghafal rumus tersebut tanpa memahami maknanya.

Belajar dan mengajar dalam proses pendidikan merupakan dua kegiatan yang saling berkaitan dan tidak dapat dipisahkan satu sama lain. Setelah belajar matematika siswa mampu mendemonstrasikan pengetahuan dan keterampilan matematikanya dimana sebelumnya ia tidak dapat melakukannya (Hudojo, 2005). Berkaitan dengan matematika, Nickson mengemukakan bahwa pembelajaran matematika adalah memberikan bantuan kepada siswa untuk membangun konsep atau prinsip matematika dengan kemampuan sendiri melalui proses internalisasi sehingga konsep atau prinsip itu terbangun (Hudojo, 2005). Jadi pembelajaran secara sadar untuk membangun konsep atau prinsip matematika dalam diri siswa. Oleh karena itu, agar proses belajar matematika terjadi, maka seyogyanya materi matematika tidak disajikan dalam bentuk yang sudah tersusun secara 
final, melainkan peserta didik dapat terlibat aktif dalam menemukan konsep, struktur sampai kepada teorema atau rumus. Keterlibatan siswa ini dapat terjadi bila bahan yang disusun dan disajikan itu bermakna bagi siswa, sehingga terjadinya interaksi antara pendidik dan peserta didik menjadi efektif.

Guru harus mengubah perannya, tidak lagi hanya sebagai pemegang otoritas tertinggi keilmuan, tetapi menjadi fasilitator yang membimbing siswa ke arah pembentukan pengetahuan oleh diri mereka sendiri (Hadi, 2005). Banyak model dan strategi pembelajaran yang dapat dilakukan untuk membantu peserta didik mengkonstruk sendiri pengetahuannya. Salah satunya adalah pembelajaran kooperatif. Pembelajaran kooperatif memberi ruang yang cukup besar untuk berinteraksi dengan orang lain sehingga dapat memunculkan ide-ide yang dapat membantu untuk mengkonstruk konsep matematika. Selain itu pembelajaran kooperatif dapat menumbuhkan keterampilanketerampilan sosial yang dapat digunakan sebagai bekal untuk hidup bermasyarakat.

Pembelajaran kooperatif memiliki berbagai macam tipe antara lain: Student TeamAchievement Divisions (STAD), Jigsaw, Think-Pair-Share (TPS), Numbered-HeadsTogether (NHT), Teams-Games-Tournaments (TGT). Masing-masing tipe memiliki karakteristik tertentu yang membedakan satu tipe dengan tipe yang lain. Salah satu ciri/karakteristik pembedanya adalah cara/aturan pembentukan kelompoknya (Asma, 2006).

Aturan/prosedur pembentukan kelompok dalam pembelajaran kooperatif yang berbeda-beda ini, seringkali membuat para pendidik di sekolah enggan untuk menggunakan pembelajaran kooperatif di kelasnya, karena dianggap terlalu rumit. Mereka lebih memilih menggunakan pembelajaran konvensional. Sebenarnya hal ini dapat diatasi kalau pendidik tidak menggunakan cara manual untuk membentuk kelompok dalam pembelajaran kooperatif.

Perbedaan cara pembentukan kelompok inilah yang seringkali menjadi kesulitan atau penghambat jika seorang pendidik ingin menggunakan pembelajaran kooperatif. Hal ini memang benar ketika pembentukan kelompok dilakukan secara manual, apalagi banyaknya peserta didik dalam kelas cukup besar. Oleh karena itu diperlukan sebuah inovasi untuk mempermudah proses pembentukan kelompok dalam pembelajaran kooperatif. Peneliti mencoba untuk mengembangkan sebuah aplikasi menggunakan bahasa pemrograman visual basic agar mempermudah pembentukan kelompok 
kooperatif berdasarkan kemampuan akademik yang heterogen. Penggunaan bahasa pemrograman visual basic dapat menjadi salah satu solusi untuk masalah tersebut.

Pengembangan ini dilakukan untuk mempermudah proses kegiatan pembelajaran yang dilakukan oleh pendidik dengan menggunakan pembelajaran kooperatif berbasis aplikasi. Pengembangan aplikasi ini akan sangat membantu khususnya dalam hal pembentukan kelompok dalam pembelajaran kooperatif. Tujuan dari penelitian ini adalah untuk mengembangkan aplikasi pembentukan kelompok cooperative learning menggunakan visual basic serta untuk mengetahui kevalidan, keefektifan, dan kepraktisan hasil pengembangan aplikasi tersebut.

\section{METODE PENELITIAN}

Model pengembangan yang digunakan adalah Research and Development (R\&D) dengan pendekatan kualitatif. R\&D adalah metode penelitian yang digunakan untuk menghasilkan produk tertentu, dan menguji kefektifan produk tersebut (Sudaryono, 2013). R\&D merupakan penelitian yang melewati langkah-langkah untuk menghasilkan produk tertentu dan menguji keefektifan produk tersebut (Sugiyono, 2012).

R\&D merupakan jembatan antara penelitian dasar (basic research) dengan penelitian terapan (applied research), dimana penelitian dasar bertujuan untuk "to discover knowledge about fundamental phenomena" dan applied research bertujuan untuk menemukan pengetahuan yang secara praktis dapat diaplikasikan (Sugiyono, 2012). R\&D sendiri bertujuan untuk menemukan, mengembangkan dan memvalidasi suatu produk.

Produk ini berbentuk software (perangkat lunak) seperti media pembelajaran berbasis IT di kelas maupun laboratorium. Pengembangan media pembelajaran ini mengadopsi dari model pengembangan Sugiyono (2012) yang terdiri dari 10 tahap, diantaranya: tahap potensi dan masalah, tahap pengumpulan data, tahap desain produk, tahap validasi desain, tahap perbaikan desain, tahap uji coba produk, tahap revisi produk, tahap uji coba pemakaian, tahap revisi produk, dan tahap produksi massal. Berdasarkan model R\&D yang dikembangkan oleh Sugiyono (2012) dengan melakukan modifikasi hanya sampai tahap revisi produk sesudah uji coba saja. Hal ini disebabkan penelitian ini hanya sebatas melakukan pengembangan, bukan untuk membuat produk secara massal. Hasil modifikasi dalam model Sugiyono disajikan pada Gambar 1 berikut. 


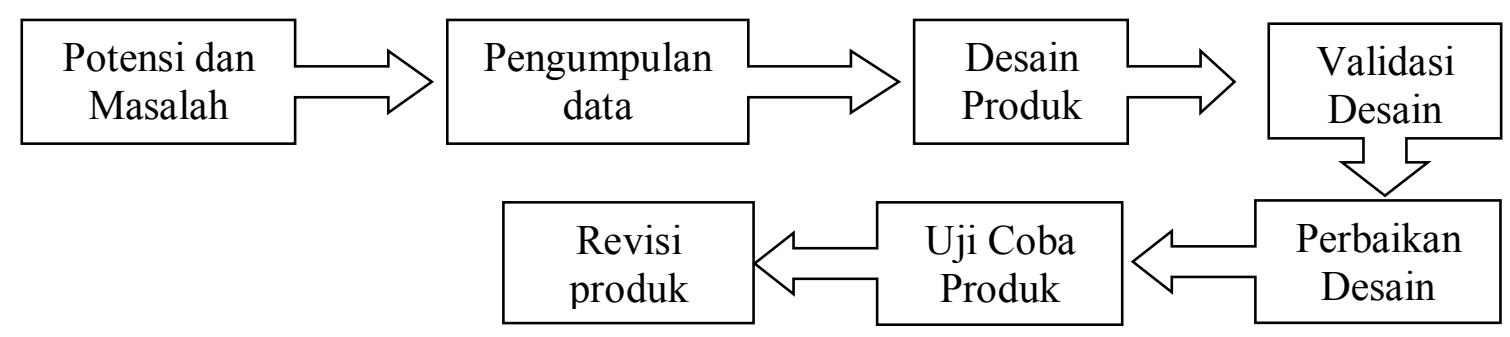

\section{Gambar 1.}

Model Desain Pengembangan

Subjek uji coba dalam penelitian ini sebanyak 2 orang dosen. Subjek uji coba pertama merupakan dosen pendidikan matematika dan subjek uji coba kedua merupakan dosen statistik UIN Sunan Ampel Surabaya. Data penelitian ini adalah data kuantitatif. Pengumpulan data dilakukan melalui angket dan wawancara.

Teknik analisis data dilakukan dengan menggunakan teknik analisis data deskriptif kuantitatif, yaitu dengan menganalisis data yang diperoleh dari angket uji ahli dan uji lapangan. Data tersebut juga ditafsirkan dengan kalimat yang bersifat kualitatif. Data untuk kualitas aplikasi pembentukan kelompok kooperatif menggunakan visual basic akan dilihat validitasnya.

\section{HASIL DAN PEMBAHASAN}

Produk yang dihasilkan pada penelitian ini berupa aplikasi pembentukan kelompok cooperative learning menggunakan visual basic. Langkah awal dalam pembuatan aplikasi ini dimulai dengan pembuatan skrip. Pada Tabel 1 disajikan contoh deklarasi program atau bahasa pemrograman dalam pengembangan aplikasi pembentukan kelompok cooperative learning menggunakan visual basic. 
Tabel 1.

Contoh Deklarasi Program atau Bahasa Pemograman Menggunakan Visual Basic

\begin{tabular}{|c|c|c|}
\hline NO & NAMA & DEKLARASI PROGRAM \\
\hline 1 & $\begin{array}{c}\text { Tampilan } \\
\text { Awal }\end{array}$ & $\begin{array}{l}\text { Public Class input } \\
\text { Dim A As Integer } \\
\text { Private Sub input_Load(ByVal sender As System.Object, ByVal e } \\
\text { As System.EventArgs) Handles MyBase.Load } \\
\text { Timer1.Enabled = True } \\
\text { 'Label1.Text = "PEMBENTUKAN KELOMPOK" \& vbCrLf \& " } \\
\text { PEMBELAJARAN KOOPERATIF" } \\
\text { A = } 0 \\
\text { End Sub } \\
\text { Private Sub Timer1_Tick(ByVal sender As System.Object, ByVal } \\
\text { e As System.EventArgs) Handles Timer1.Tick } \\
\text { ProgressBar1.Value = A } \\
\text { A = A + 1 } \\
\text { If A }>=100 \text { Then } \\
\text { Me.Hide() } \\
\text { Form1.Show }() \\
\text { Timer1.Enabled = False } \\
\text { End If } \\
\text { End Sub } \\
\text { End Class }\end{array}$ \\
\hline 2 & $\begin{array}{c}\text { Tampilan } \\
\text { Utama }\end{array}$ & 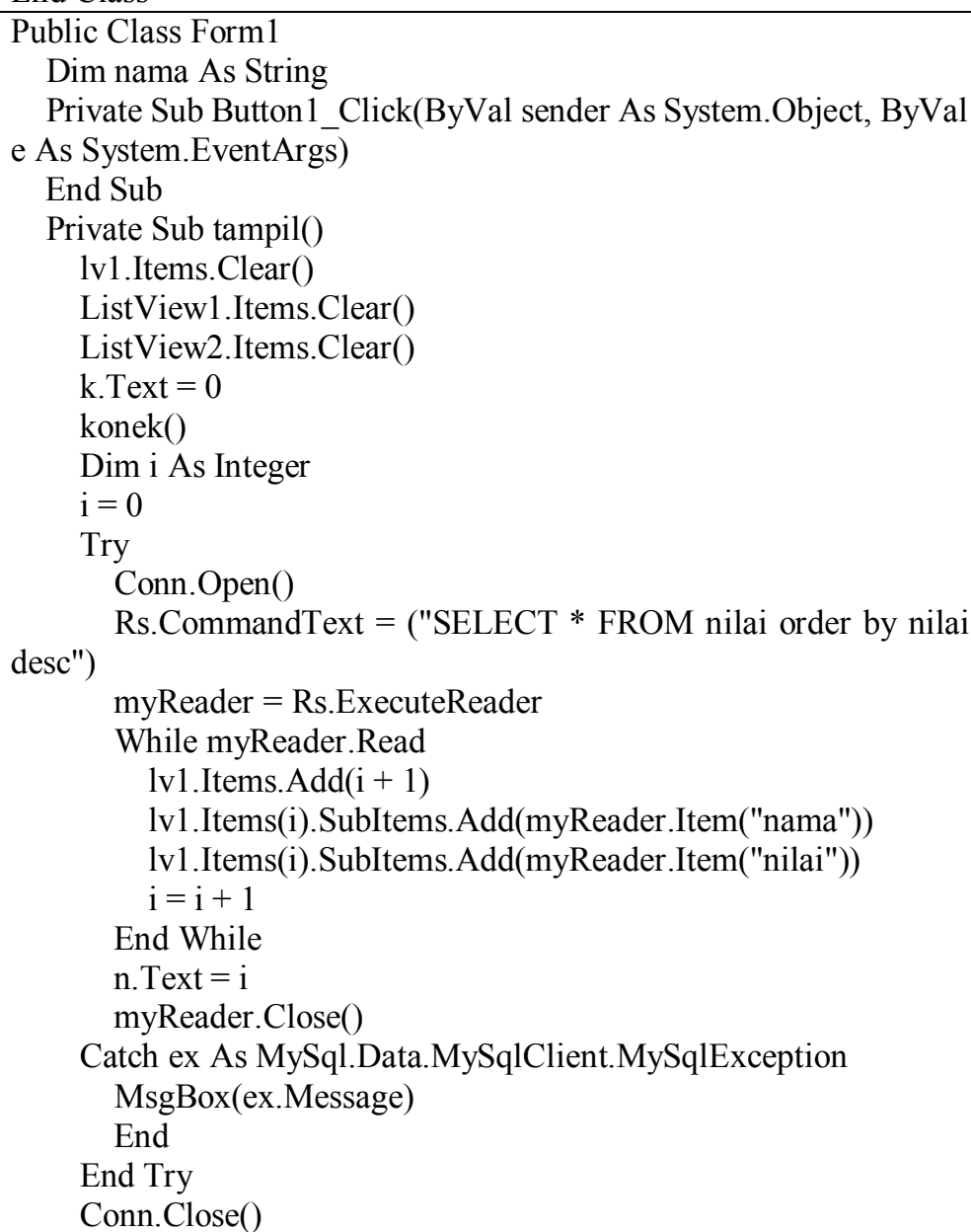 \\
\hline
\end{tabular}




\begin{tabular}{|c|c|c|}
\hline NO & NAMA & DEKLARASI PROGRAM \\
\hline & & 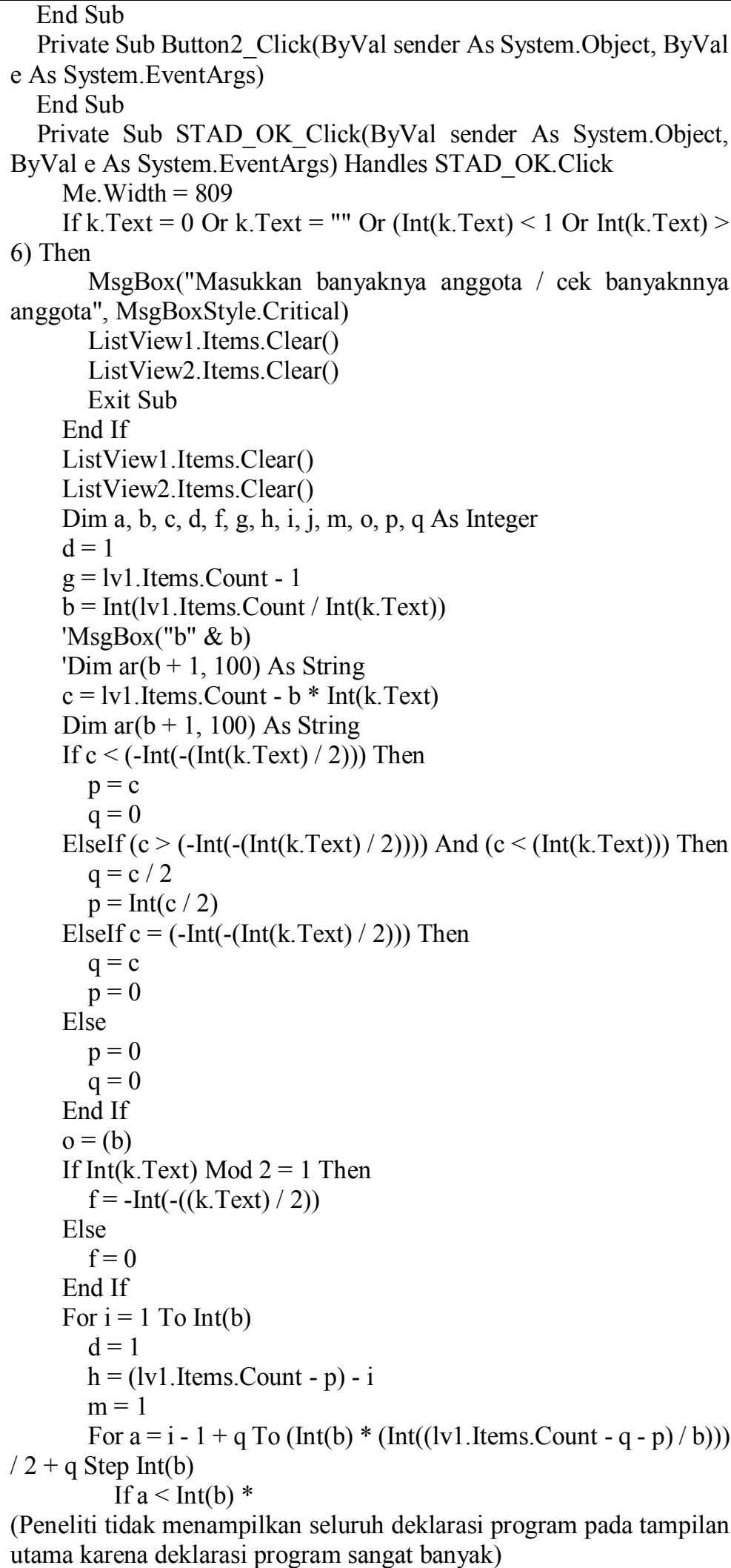 \\
\hline 3 & $\begin{array}{l}\text { Tampilan } \\
\text { Penskoran }\end{array}$ & $\begin{array}{l}\text { Public Class perhitungan } \\
\text { Private Sub perhitungan_Load(ByVal sender As System.Object, } \\
\text { ByVal e As System.EventArgs) Handles MyBase.Load } \\
\text { tampil() }\end{array}$ \\
\hline
\end{tabular}




\begin{tabular}{|c|c|c|}
\hline NO & NAMA & DEKLARASI PROGRAM \\
\hline & & 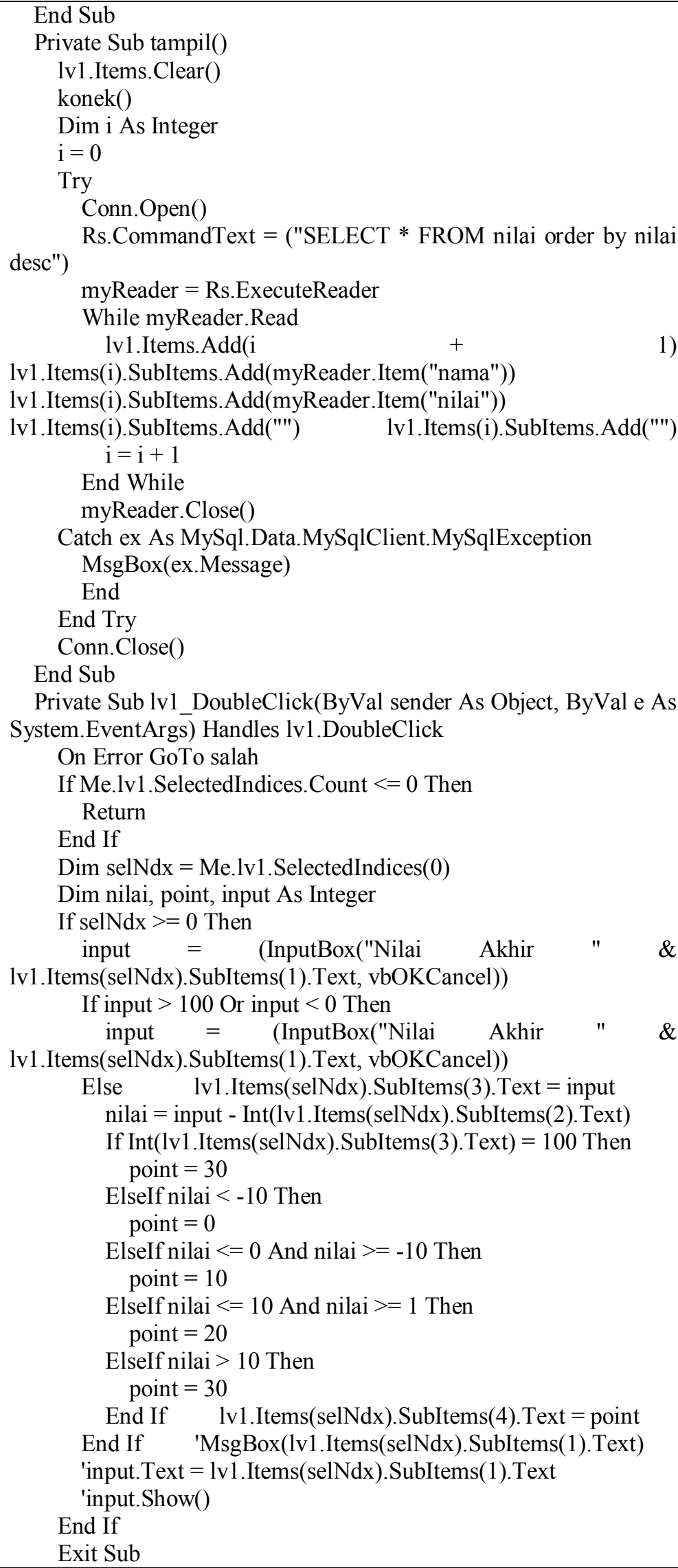 \\
\hline
\end{tabular}




\begin{tabular}{|c|c|c|}
\hline NO & NAMA & DEKLARASI PROGRAM \\
\hline & & $\begin{array}{l}\text { salah: } \\
\text { MsgBox("Masukkan angka") } \\
\text { End Sub } \\
\text { Private Sub lv1_SelectedIndexChanged(ByVal sender As } \\
\text { System.Object, ByVal e As System.EventArgs) Handles } \\
\text { lv1.SelectedIndexChanged } \\
\quad \text { End Sub } \\
\text { End Class }\end{array}$ \\
\hline
\end{tabular}

Berikut ditunjukkan aplikasi pembentukan kelompok cooperative learning menggunakan visual basic. Pada Gambar 2 ditunjukkan tampilan awal aplikasi ketika program dibuka. Gambar 2 hanya memperlihatkan tampilan awal dari aplikasi ini.

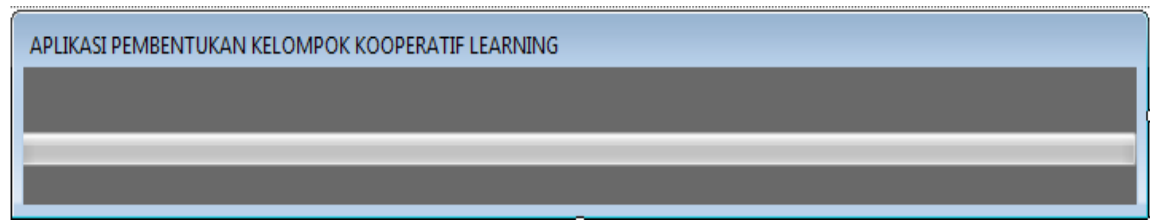

Gambar 2.

Tampilan Awal Aplikasi

Berikut ini merupakan tampilan menu yang berisi daftar nama mahasiswa dan nilai pada pertemuan sebelumnya. Selain itu terdapat menu pilihan tipe cooperative learning yang dipakai. Pada menu ini juga harus diinputkan total mahasiswa di kelas beserta banyaknya anggota yang diinginkan pada setiap kelompok sebagaimana yang disajikan pada Gambar 3. 


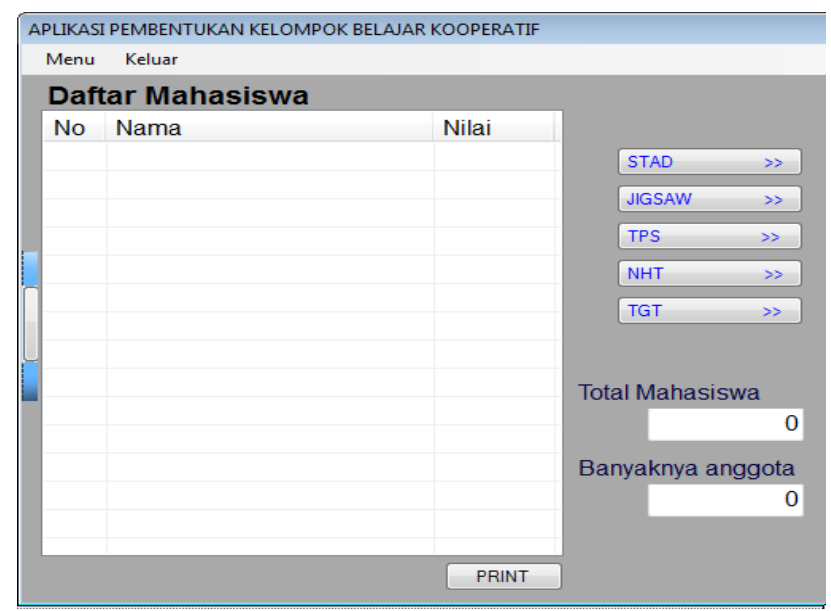

Gambar 3.

Tampilan Menu Awal Aplikasi

Pada Gambar 4 disajikan menu tampilan untuk menginputkan nama mahasiswa dan nilainya. Pada tampilan menu ini juga dilengkapi menu tambah, simpan, dan hapus untuk mengedit input nama yang sudah dilakukan.

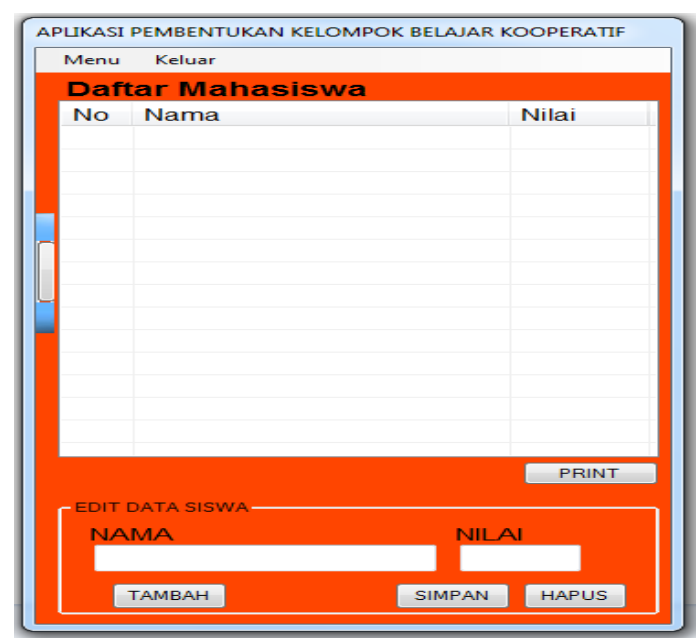

Gambar 4.

Menu Edit Data

Pada Gambar 5 ditunjukkan tampilan menu hasil pengacakan pembentukan kelompok cooperative learning sesuai dengan tipe STAD, TPS dan NHT. Dari tampilan ini terlihat banyak kelompok dan banyak anggota masing-masing kelompok berdasarkan jumlah total banyaknya mahasiswa di kelas. 


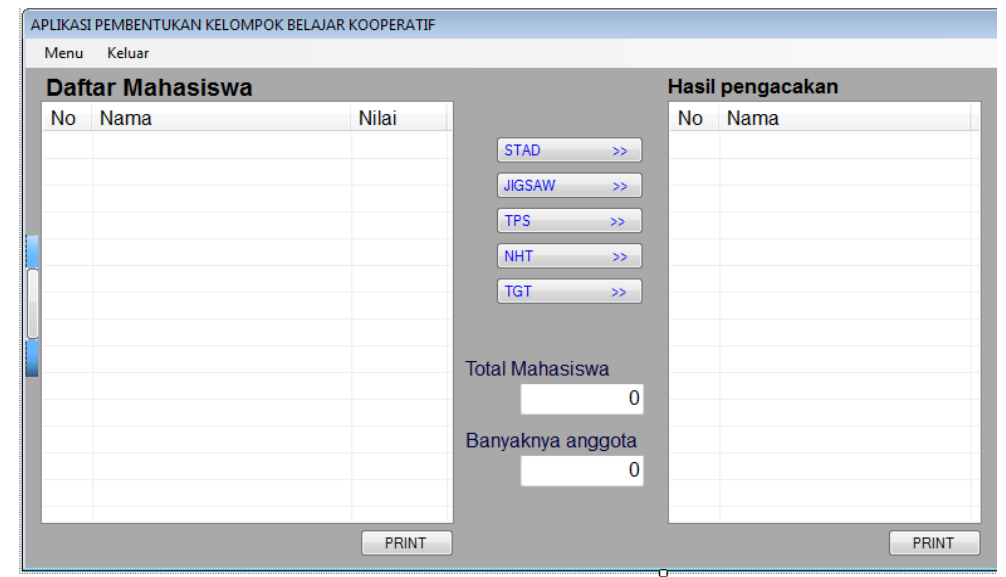

Gambar 5.

Tampilan Pilihan Model Cooperative Learning

Pada Gambar 6 juga ditunjukkan tampilan menu hasil pengacakan pembentukan kelompok cooperative learning sesuai dengan tipe JIGSAW dan TGT. Dari tampilan ini terlihat banyak kelompok dan banyak anggota masing-masing kelompok berdasarkan jumlah total banyaknya mahasiswa di kelas

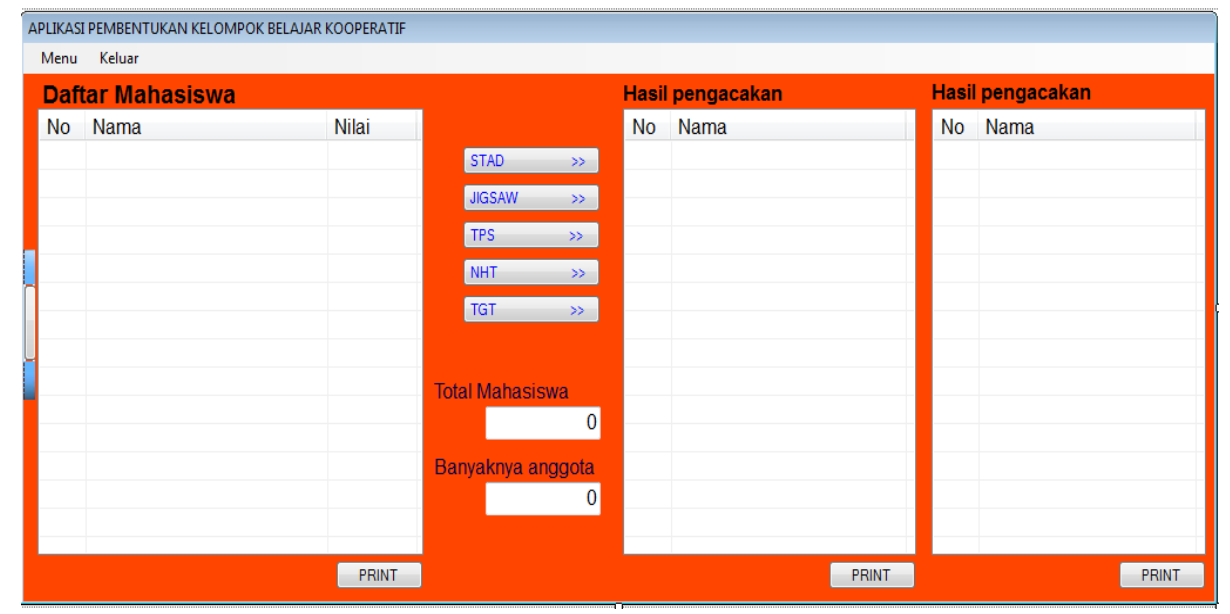

Gambar 6.

Tampilan Pilihan Model Cooperative Learning

Pada Gambar 7 ditunjukkan tampilan menu penskoran nilai mahasiswa. Pada menu ini diinputkan nama mahasiswa, skor dasar yang merupakan skor tugas/kuis pada tugas sebelumnya, skor sekarang yang merupakan skor tugas/quiz pada pertemuan saat diberlakukan cooperative learning. Setelah nama, skor dasar dan skor sekarang terinputkan maka secara otomatis skor perkembangan akan muncul. 


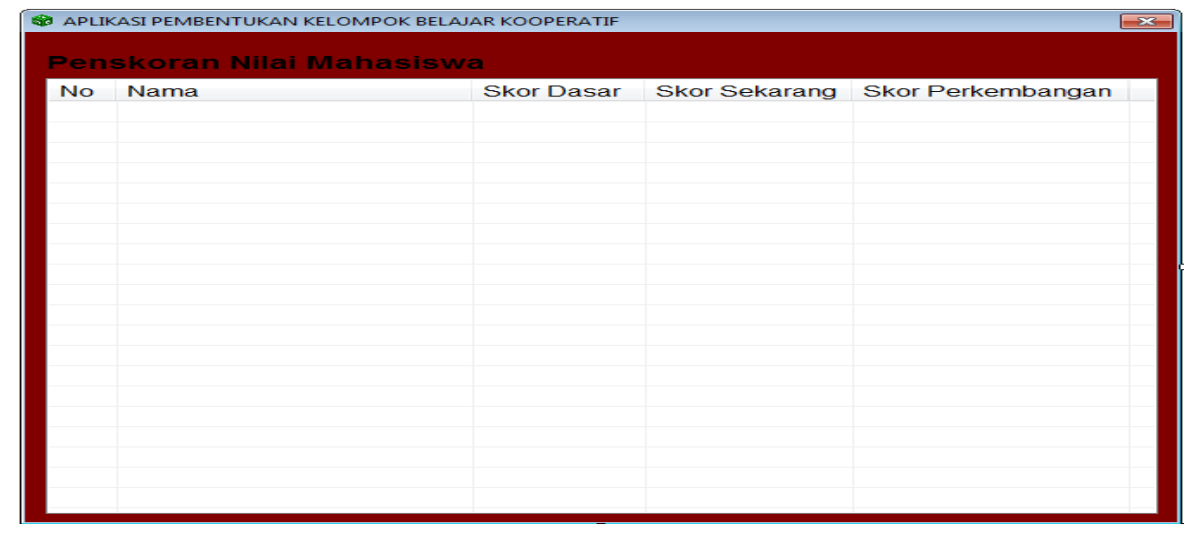

Gambar 7.

Menu Penskoran dalam Aplikasi

Tahapan potensi dan masalah pada penelitian ini diawali dengan memberikan angket respon pada dua orang dosen di prodi pendidikan matematika. Kedua responden diminta mengisi angket terkait dengan penggunaan model pembelajaran kooperatif. Berdasarkan angket tersebut diketahui bahwa responden yang menggunakan model pembelajaran kooperatif dalam perkuliahannya merasa kesulitan dalam membentuk kelompok kooperatif, walaupun dilakukan akan tetapi responden merasa belum efektif dalam membentuk kelompok kooperatif karena perbedaan karakteristik tiap tipe pada model pembelajaran kooperatif sehingga berbeda pula cara membentuk kelompoknya. Kedua responden juga setuju jika ada sebuah aplikasi yang dapat membantu mereka membentuk kelompok dalam pembelajaran kooperatif.

Setelah dilakukan tahap potensi dan masalah berikutnya dibuat produk aplikasi pembentukan kelompok. Untuk mengetahui kualitas produk tersebut maka dilakukan uji coba produk terhadap responden. Kedua responden setuju bahwa aplikasi pembentukan kelompok cooperative learning menggunakan visual basic merupakan hal baru. Seluruh tampilan yang ada dalam aplikasi ini menarik, mudah dalam pengoperasian, sangat membantu dalam pembentukan kelompok cooperative learning. Kedua respondenpun sangat mendukung penggunaan aplikasi ini untuk para pendidik yang menggunakan cooperative learning.

Dalam penelitian pengembangan aplikasi ini, data yang didapat dari hasil validasi ahli digunakan untuk mengukur tingkat kevalidan aplikasi yang dikembangkan. Untuk data yang diperoleh dari hasil validasi dosen digunakan untuk mengukur tingkat kepraktisan aplikasi tersebut. Sedangkan untuk keefektifan aplikasi tersebut, digunakan data yang diperoleh dari hasil angket respon dosen. Sehingga, proses penilaian kualitas 
aplikasi pembentukan kelompok cooperative learning menggunakan visual basic diperoleh dari hasil validasi yang dilakukan oleh ahli dan dosen, serta angket respon dosen. Berikut adalah hasil penilain yang dilakukan oleh ahli.

Tabel 2.

Hasil Validasi oleh Ahli

\begin{tabular}{clcccc}
\hline Aspek & \multicolumn{1}{c}{ Komponen } & $\begin{array}{c}\text { Ahli } \\
\text { media } \\
\text { IT }\end{array}$ & $\begin{array}{c}\text { Ahli } \\
\text { Materi }\end{array}$ & $\begin{array}{c}\text { Nilai } \\
\text { Rata- } \\
\text { rata }\end{array}$ & \% \\
\hline Tampilan & $\begin{array}{l}\text { Kesesuaian tiap-tiap menu dengan } \\
\text { konsep pembentukan kelompok } \\
\text { cooperative learning }\end{array}$ & 5 & 5 & 5 & $100 \%$ \\
$\begin{array}{l}\text { Kesesuaian warna, tulisan, dan } \\
\text { gambar pada aplikasi } \\
\text { pembentukan kelompok } \\
\text { cooperative learning }\end{array}$ & 4 & 5 & 4.5 & $90 \%$ \\
Kesesuaian antara konten dalam \\
aplikasi pembentukan kelompok \\
dengan aspek-aspek dalam \\
$\begin{array}{l}\text { cooperative learning } \\
\text { Kejelasan konsep aplikasi } \\
\text { pembentukan kelompok } \\
\text { cooperative learning } \\
\text { Aplikasi ini mempermudah } \\
\text { pendidik melakukan pembentukan } \\
\text { kelompok cooperative learning } \\
\text { Kemudahan dalam memahami } \\
\text { bahasa yang digunakan } \\
\text { Kelengkapan kalimat informasi } \\
\text { yang dibutuhkan dalam } \\
\text { pengoperasian aplikasi ini }\end{array}$
\end{tabular}

Dari Tabel 2, jika melihat dari hasil nilai yang didapatkan baik validasi ahli maupun dosen, semua menunjukkan nilai yang tinggi dalam aspek tampilan, materi, kepraktisan dan bahasa. Aplikasi pembentukan kelompok cooperative learning menggunakan visual basic ini dapat dikatakan sangat layak dalam semua aspek tersebut. Sedangakan secara keseluruhan aplikasi pembentukan kelompok cooperative learning menggunakan visual basic juga dapat dikatakan sangat layak. Dilihat persentase total yang didapat dari hasil 
validasi ahli sebesar $82,5 \%$ dan validasi dosen $92,86 \%$. Sehingga menurut persentase pencapaian nilai tersebut menunjukkan pada interpretasi $84 \% \leq \bar{x} \leq 100 \%$.

Disamping itu, dari hasil angket respon dan wawancara kepada dosen, aplikasi pembentukan kelompok cooperative learning menggunakan visual basic menunjukkan nilai sangat tinggi yang disajikan pada Tabel 3 di bawah ini.

Tabel 3.

Hasil Angket Respon Subjek Sesudah Tahap Uji Coba

\begin{tabular}{|c|c|c|c|}
\hline No & Pertanyaan & Dosen 1 & Dosen 2 \\
\hline 1 & $\begin{array}{l}\text { Apakah aplikasi pembentukan } \\
\text { kelompok cooperative learning } \\
\text { menggunakan visual basic merupakan } \\
\text { hal baru bagi anda }\end{array}$ & 2 & 2 \\
\hline 2 & $\begin{array}{l}\text { Apakah seluruh tampilan yang ada } \\
\text { dalam aplikasi ini menarik }\end{array}$ & 1 & 2 \\
\hline 3 & $\begin{array}{l}\text { Apakah anda mudah dalam } \\
\text { pengoperasian aplikasi ini }\end{array}$ & 2 & 2 \\
\hline 4 & $\begin{array}{l}\text { Apakah menu yang terdapat pada } \\
\text { aplikasi sudah cukup? }\end{array}$ & 1 & 1 \\
\hline 5 & $\begin{array}{l}\text { Apakah dengan adanya aplikasi ini } \\
\text { sangat membantu anda dalam } \\
\text { pembentukan kelompok pembentukan } \\
\text { kelompok cooperative learning }\end{array}$ & 2 & 2 \\
\hline 6 & $\begin{array}{l}\text { Bagaimana tanggapan anda, jika } \\
\text { aplikasi ini digunakan dosen/tenaga } \\
\text { pendidik dalam proses pembelajaran }\end{array}$ & 2 & 2 \\
\hline \multicolumn{2}{|r|}{ Jumlah skor yang diperoleh } & 10 & 11 \\
\hline \multicolumn{2}{|c|}{ Rata-rata } & 0,833 & 0,917 \\
\hline \multicolumn{2}{|c|}{ Persentase } & $83,33 \%$ & $91,67 \%$ \\
\hline
\end{tabular}

Tabel 3 menunjukkan persentase total yang didapat dari hasil angket respon kedua dosen tersebut, masing-masing memperoleh 83,33\% untuk subjek uji coba pertama. Sedangkan untuk subjek uji coba kedua memperoleh 91,67\%. Sehingga menurut persentase pencapaian nilai tersebut menunjukkan pada interpretasi $75 \% \leq \bar{x} \leq 100 \%$. Jadi disimpulkan bahwa aplikasi pembentukan kelompok cooperative learning menggunakan visual basic ini benilai positif atau sangat membantu dosen dalam proses pembentukan kelompok cooperative learning.

Berdasarkan penjelasan di atas, baik dari hasil validasi ahli maupun hasil angket respon dosen, dapat disimpulkan bahwa kualitas aplikasi ini sangat layak dijadikan alat bantu dosen untuk pembentukan kelompok cooperative learning. Tahapan revisi produk 
dilakukan berdasarkan hasil saran dan masukan yang diberikan oleh validator. Berikut ini uraian singkat tentang revisi desain yang disajikan pada Tabel 4.

Tabel 4.

Daftar Revisi Desain oleh Dua Validator

\begin{tabular}{ccc}
\hline No & Sebelum Revisi & Sesudah Revisi \\
\hline 1 & Tampilan menu awal kurang menarik & Tampilan menu awal lebih \\
& dan pemilihan warna terlalu & menarik dan telah dipilih warna \\
& mencolok dan tidak konsisten & yang kontras \\
2 & Terdapat eror pada bagian edit data & Tidak ada eror \\
3 & Belum dilengkapi sintak tipe & Telah dilengkapi karakteristik tipe \\
& cooperative learning & cooperative learning \\
\hline
\end{tabular}

Berdasarkan Tabel 4, aplikasi ini direvisi sehingga menghasilkan aplikasi yang lebih baik sebagaimana saran dan masukan dari dua validator.

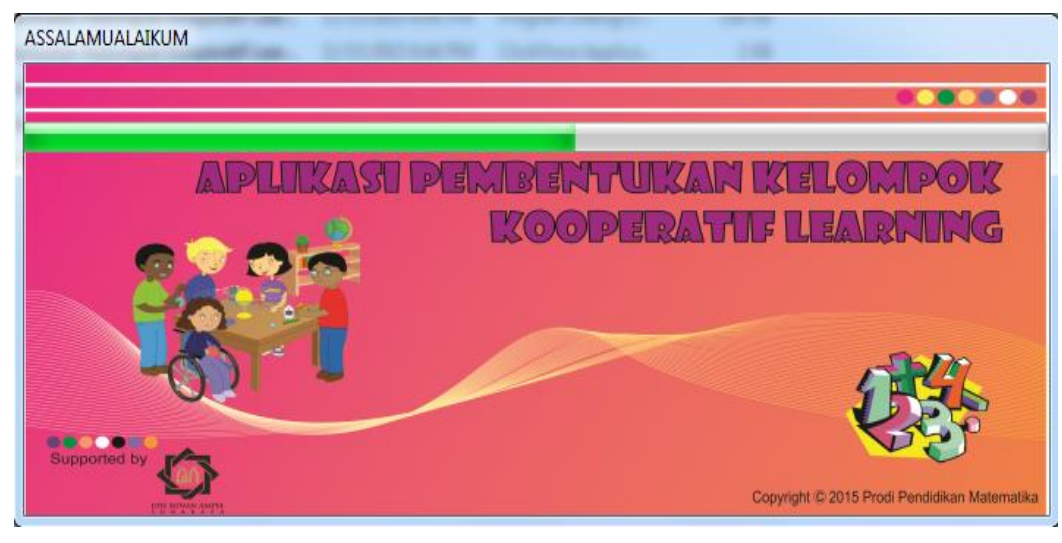

Gambar 8.

Tampilan Awal Aplikasi

Pada Gambar 8, menunjukkan tampilan awal ketika baru dibuka aplikasi pembentukan kelompok Cooperative Learning menggunakan Visual Basic berdasarkan hasil revisi dari dua validator. 


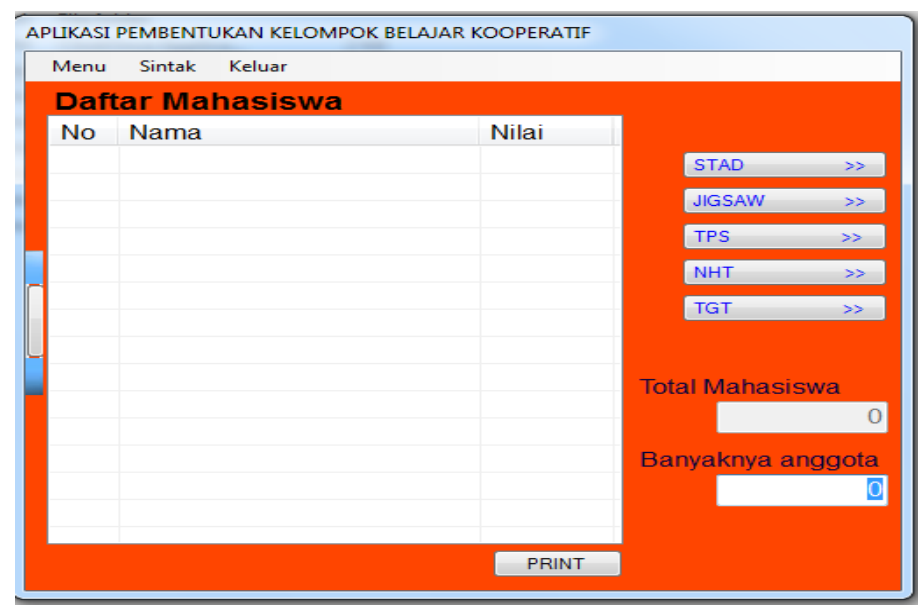

\section{Gambar 9.}

Tampilan Menu Awal

Pada Gambar 9, menunjukkan tampilan menu awal aplikasi pembentukan kelompok Cooperative Learning menggunakan Visual Basic berdasarkan hasil revisi dari dua validator.

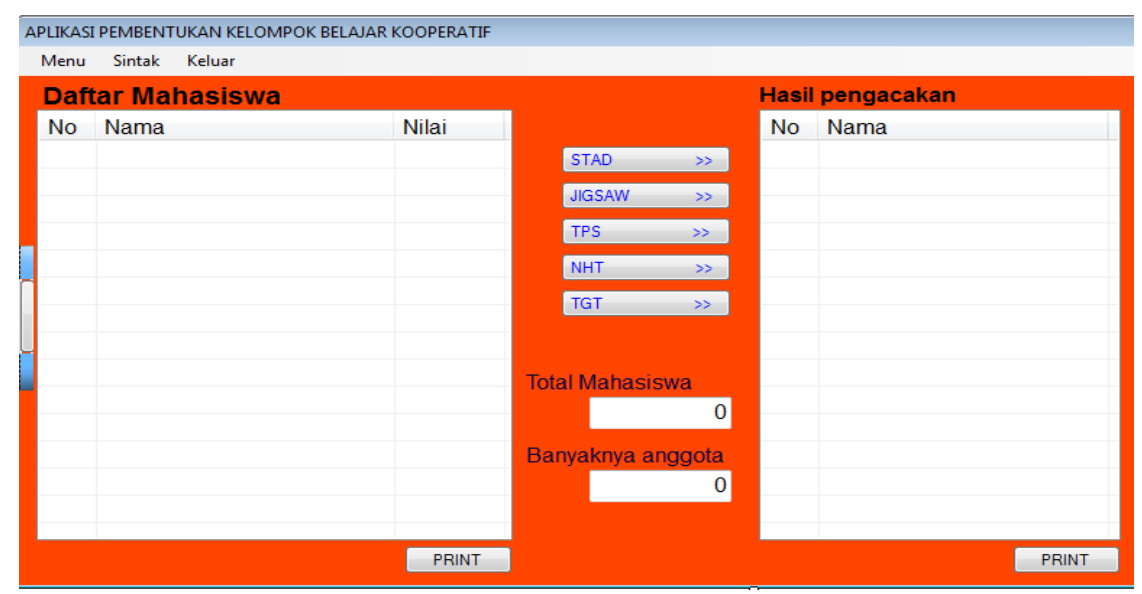

\section{Gambar 10.}

Tampilan Pilihan Model Cooperative Learning

Pada Gambar 10, menunjukkan tampilan pilihan model pembelajaran Cooperative Learning, diantaranya STAD, JIGSAW, TPS, NHT, dan TGT aplikasi pembentukan kelompok Cooperative Learning menggunakan Visual Basic berdasarkan hasil revisi dari dua validator. 


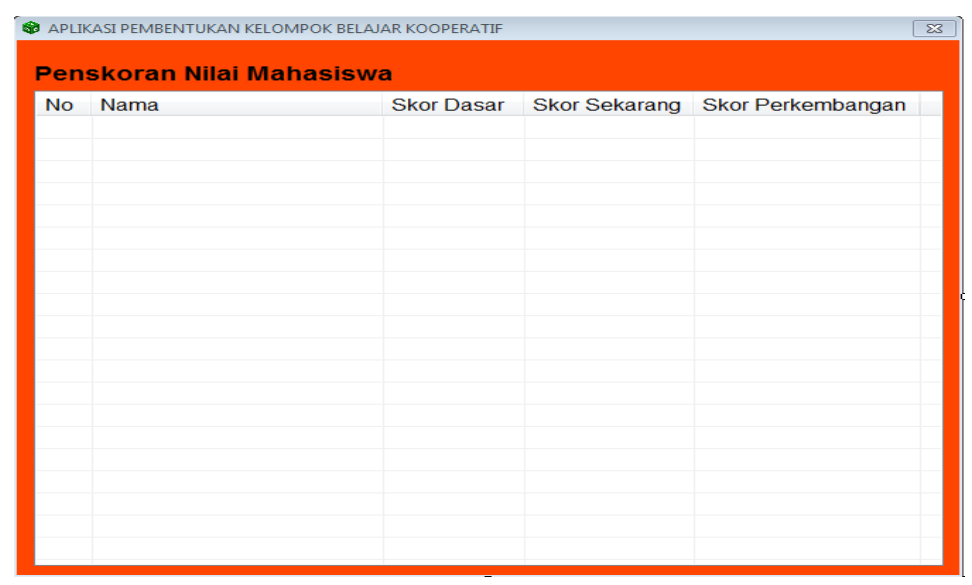

Gambar 11.

Menu Penskoran

Pada Gambar 11, menunjukkan menu penskroran dalam aplikasi pembentukan kelompok Cooperative Learning menggunakan Visual Basic berdasarkan hasil revisi dari dua validator.

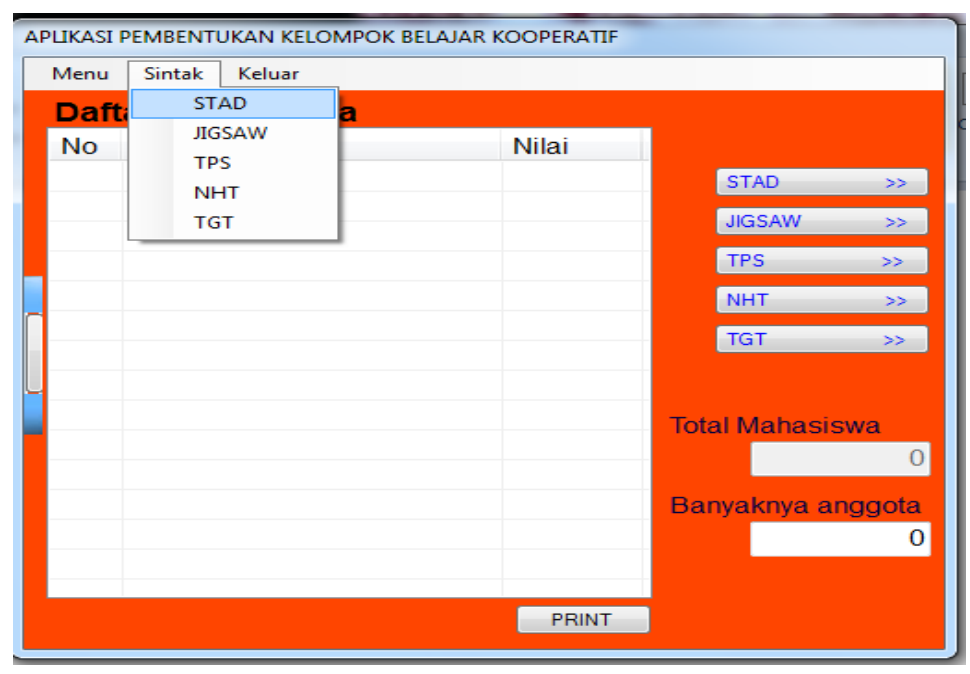

Gambar 12.

Menu Sintaks

Pada Gambar 12, menunjukkan pilihan menu sintaks dari tipe STAD, JIGSAW, TPS, NHT, dan TGT yang telah dilengkapi dengan karakteristik masing-masing dalam aplikasi pembentukan kelompok Cooperative Learning menggunakan Visual Basic berdasarkan hasil revisi dari dua validator. 


\section{SIMPULAN DAN SARAN}

Aplikasi pembentukan kelompok cooperative learning menggunakan visual basic terdiri dari beberapa bagian yakni input data nama dan nilai peserta didik, tipe pembelajaran kooperatif yang dipilih, sintak pembelajaran kooperatif, desain tempat duduk, dan pembentukan kelompok yang diinginkan.

Saran-saran yang dapat diberikan peneliti sebagai sumbangan pemikiran terhadap pengembangan aplikasi pembentukan kelompok cooperative learning menggunakan visual basic selanjutnya sebagai berikut: (1) perlu juga dikembangkan aplikasi yang support terhadap perangkat selain komputer, seperti smartphone dan tablet, dan (2) alangkah baiknya sebelum menggunakan aplikasi ini pengguna membaca literatur terkait cooperative learning sehingga mempermudah penggunaan aplikasi ini.

\section{DAFTAR RUJUKAN}

Asma, N. (2006). Model pembelajaran kooperatif. Jakarta: Departemen Pendidikan Nasional Direktorat Jendral Pendidikan Tinggi.

Hadi, S. (2005). Pendidikan matematika realistik dan implementasinya. Banjarmasin: Tulip Banjarmasin.

Hudojo, H. (2005). Pengembangan kurikulum dan pembelajaran matematika. Malang: UM Press.

Sugiyono. (2012). Metode penelitian pendidikan "Pendekatan kuantitatif, kualitatif, dan $R \& D ”$. Bandung: Alfabeta.

Sudaryono. (2013). Pengembangan instrumen penelitian pendidikan. Yogyakarta: Graha ilmu. 